\title{
Ceramic Education in Contemporary Art Background
}

\author{
Ling Guo \\ East China Normal University \\ Shanghai, China
}

\begin{abstract}
Ceramics was born in discovery and opportunity of life. Ancestors cleverly used clay, through technology improvement made it the ceramic vessel. On one hand, it means human conquered the water, fire and dirt, use intelligence to transform the material environment so to make human step into civilization society; on the other hand, during human's discovery and application process, through the fine division of technology, it also expanded the technology and intelligence of practical field, so to make ceramics has become a living artwork with aesthetic function. China is the ancient capital of ceramics, one is because the long history and sophisticated technology, other reason is the ancestors through continuous discovery and improvement of new technology, successfully created a variety of fine ceramic works. In today's era ceramics faces many opportunities and challenges. We have to inherit the ceramic traditions along the ages, and also we need to emphasize individuality and innovation in the traditional classical forms, in order to reflect the humanistic care of native culture, so that to make it worthy of the good fame as country of ceramics. It is the starting point of the article. This article focuses on the current situation of the two main education groups and compares the educations in different colleges and universities.
\end{abstract}

\section{Keywords - contemporary art; ceramic art; oriental culture}

\section{INTRODUCTION}

The birth of ceramics is the carrier of Chinese national culture, she has a long history and rich cultural heritage. She also has doomed oriental cultural character of subtle, stability and tranquility. Chinese ceramics is not just a simple artistic media, it is also an art form which reflects Chinese national culture, it contains a profound oriental aesthetics. In contemporary art it could make better to highlight this quality.

\section{CERAMIC ART EDUCATION UNDER CONTEMPORARY ART BACKGROUND}

\section{A. Development of Ceramics History}

For the entire history of mankind, the power of the spirit is great and far-reaching, ceramics development is also the same. Spiritual strength inspired constant innovation and updates of ceramics, promote the ceramic art performance continuous distillation. In order to study ceramics and contemporary art, we must first understand the concept of contemporary art. Contemporary art in time refers to the art of today, in connotation it refers to the art with modern spirit and modern languages. We understand that contemporary art is not only reflects "modernity", but also with the "contemporaneity" based on today's social life experience which could reflect the time characteristics of today. But to mention the "contemporary art", we need to sort out a context which is the West went through a development process of "classical art", "Modern Art", and "contemporary art". "Classical Art" was designed to be realism, its aesthetic was determined to be "natural beauty"; the purpose of modern art was to create "meaningful" form, its aesthetic was "Artistic beauty"; However, contemporary art can not be the same like the former two, it can not be described in one word, we can only generally called it "the third field beauty", what is "the third field beauty"? It is a beauty that closely related to human life and happiness, and it is good for our body and mind. At the same time, ceramic art based on skillful technology integrate with of a firm concept support, outstanding temperament infiltration, rich cultural heritage, profound human philosophizing, which together build the Oriental cultural quality of Chinese ceramics. When East ceramics met contemporary art, the wonderful opportunity made people tried to "match" them together.

\section{WESTERN AESTHETIC THOUGHT AND ORIENTAL AESTHETIC PHILOSOPHY}

\section{A. Oriental Cultural Aesthetic Standards}

Throughout art history, at any time in her long river all has a relative mainstream values. Europe, America and Japan these Western societies have fully influence in the world today about the judge and impact no matter in classical art, modern art, or contemporary art. Which also made the contemporary art from Europe, America and Japan became a mainstream language. Development of Chinese ceramics has its own standard of value in each period, summed up were like the calm and gentle, pay attention to technical perfection, focus on the glazes not the earth, focus on painting not color. Chinese culture or Chinese ceramics is an introspective culture, Chinese people always pay attention to a subtle, restrained and Zen life philosophy. Chinese people's philosophy is to make life into wisdom, use the power to reconcile their own desire. This makes the Chinese people's thoughts are law-abiding, contentment, with few desires and focus on health care, they do not advocate physical pleasure. This culture which may look weak at transformation and obtaining of the substance, but it is very good at transformation the heart and make life into wisdom. We just need to look at the Confucianism, Taoism and Buddhism which composed the Chinese culture then we will completely understand. These are also reflected in the ceramic culture. For example, the Song Dynasty celadon in Chinese traditional ceramic heyday, celadon was negative, back light, cold escape. That was a high cold, pale world. The 
Song Dynasty Ru porcelain which the Emperor Song Huizong forced the whole country to build out, it is made of underground soil by firing to become the sky color, it fired together with the spirit of Taoism, the beauty of substance and ideal of rulers. Including the sky and the earth, this is the best expression of Chinese people's spiritual world and makes it expressed on the ceramic aesthetics all throughout. "Fig.1", "Fig. 2", "Fig. 3"

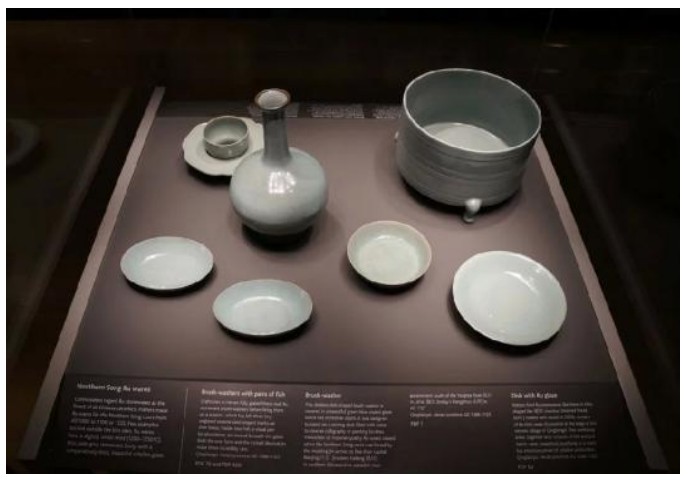

Fig. 1. London weed foundation to hide your kiln porcelain of song dynasty

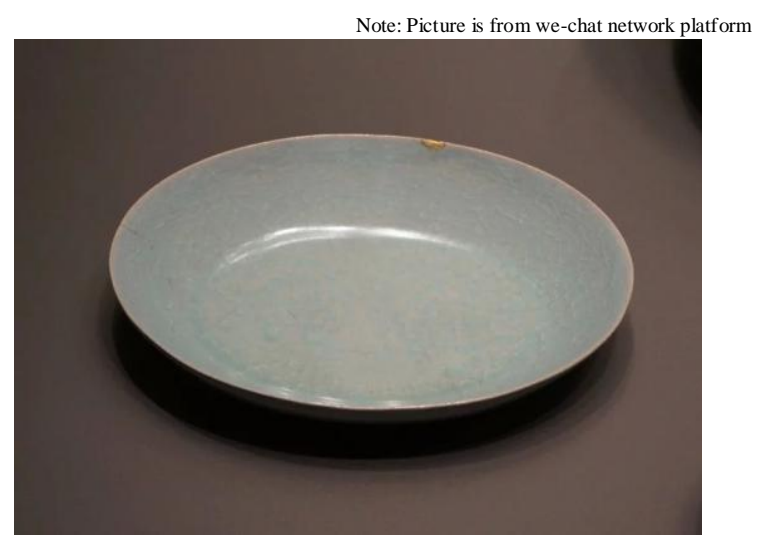

Fig. 2. London weed foundation to hide your kiln porcelain of song dynasty

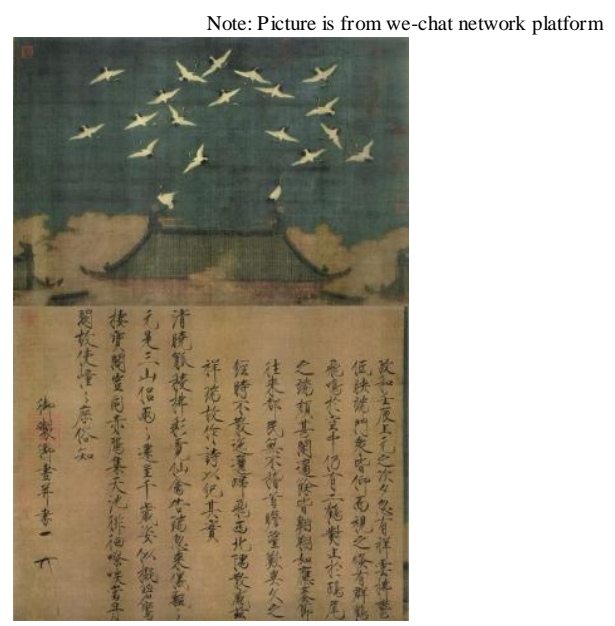

Fig. 3. Emperor Song Huizong's "Ruihe Tu"

\section{B. Fusion of Oriental and Western Culture}

Oriental culture is immutable, it is a precocious culture. As Liang Shuming said, "The precocity of Oriental Culture, inappropriate at first, but now is useable-with the development of the world, unexpectedly the opportunity comes the moment although it was inappropriate before". And indeed Liang Shuming's this analysis was a century ago. Throughout the entire art, we could also see the enormous influence of oriental culture. For example: 18th century French Rococo art style absorbed the people and scenery design elements of Chinese porcelain, thus we could see the spread function of Chinese ceramics as the Oriental culture and her own cultural character. Subsequently, the impressionist absorbed Japanese ukiyo-e planar depicting. These all reflect the internationalization of Oriental culture and its distant meaning. New York Guggenheim Museum organized a Large-scale exhibition "the third idea: American artists focus on Asia 1860--1989" in 2009. This exhibition was the first comprehensive collation about the impact of Asian culture and thought to American Art. It made Asian art and ideas have the conversion impact with the form and idea achievements of US modern art and avantgarde art. From this clue we could see the process of Western culture transformation and accumulation. The extremely profound influence of Oriental philosophic thought, especially Oriental Zen thought, this is the scholars' indisputable fact.

Ceramic education bears a big mission, it is an important context. We should not only macro-control the development of the ceramic art, and also to make ceramic art fit the time as the educator gesture. How to place the ceramic education in the Oriental and Western concepts? In this seemly conflict, in fact we have found the opportunity - Zen thought. Contemporary art from Duchamp's urinal, it has already fused with the "Zen". In Chinese ceramic culture, the celadon is pure, the black porcelain is mysterious, the white porcelain is bright clear, the furnace transmutation is brilliant, the official porcelain is elegant, and the local porcelain is simple. The Zen theme resides in Buddhism which so-called "Yujing Zizai, Liugen Huyong" is a state without separation. In the ceramic glaze and decoration, we see these comfortable whims. Whether the root self reveal brought by strokes or natural root self in kiln or shapes with hundred thoughts, they all reflect the Zen principle, and all leave the Zen philosophy, which is the Chinese people's thought ideas. In our Universities' ceramics education, educators have such great responsibility to uphold the spirit, adhere to this cultural context and heritage contemporary ceramics education.

\section{CONTEMPORARY CERAMIC ART EDUCATION DEVELOPMENT}

\section{A. Ceramic Education Status of Domestic Universities}

It was always over-emphasized on technique perfection of Chinese traditional ceramics, so many artists kept traditional ceramics at a distance and made it equate with the arts and crafts. This was relatively one-sided. In fact, many times although we were using the "ceramics" word, but for different background or different person to understand or describe it may have vary differences. This presented us with a problem, contemporary ceramics need a clear modern linear 
development, whether professional or amateur when they faced with ceramics this basic concept, it can not be different. It required a core value. Ceramic education beard such a mission, whether in Liberal or professional education, we need to make our entire national understanding of our country of ceramics rose to a basic professional level.

People with different occupations, different cultural backgrounds involved in different ways. Although they did not experience the ceramics practice language like ceramic artists, but they can properly introduce the ceramic context into real life, make it becomes feasible and full of achievements. But in ceramic education, due to the lack of exchange and communication, resulting in the faults and messy between ceramic educations, it has also led to the divergence between the traditional ceramics which gave birth to the ceramics and breed it and the academic ceramics. It is the deficiency of Chinese ceramic art education. In recent years, throughout the domestic arts education institutions, works emerge in an endless stream. We see thinking and challenge to contemporary ceramics. Ceramic university has rich creation experience, there is also a variety of many foreign scholars and exchange opportunities of further studies, the amount of information is also very big, and we have our own ceramicproducing areas' rich cultural heritage and unique geographical advantage. Many ceramic artists still choose ceramicproducing area to make their creation, it is enough to explain its attractiveness and the favorable conditions of climate, geography and human condition. But implantation of ideas and thoughts are also very important. Spirit effect is huge. Not only spirit can control people's creation awareness, and even to some extent it can influence the formation of the human selfimage features. In the life objects of nature, there is a aesthetic consciousness which transcendent humanity, the most fundamental and the most common, and closely related to the life. That is to say ceramics is inseparable from the people body and natural objects, these two are the life source of ceramics. The support of spiritual awareness behind the aesthetic sense in a large extent, it will impose conclusive influence to the external form. Therefore, as ceramic educators, we should continue to deliver this spiritual awareness in order to finish the mission of ceramic education under the contemporary art background.

At last century, the sequela caused by companies' blind production in order to pursue the interests made people deep introspection. Now during the college graduation exhibitions, we see challenges and breakthroughs "Fig. 4", "Fig. 5", "Fig. 6", "Fig. 7", "Fig. 8". This shows the contemporaneity of Ceramic Art Education, which is quietly developing. While comparing with two types of domestic institutions, one is the country's top institutions like the Academy of Fine Arts, other one is ceramic universities located in the unique ceramicproduction area. The first one focus on the expression of modeling concept, excavated ceramic material itself, express the ceramic art through the material itself("Fig. 4", "Fig. 5"); For ceramic universities, we can consider to develop the traditions based on fully reflect the unique geographical advantages of ceramic-prediction area, especially the advantages of decorative painting in ceramics such as glaze and underglaze, which is rarely reflected in the Academy of
Fine Arts but it is a very important Chinese ceramic element especially since the Song Dynasty painted ceramic has became the mainstream "Fig. 6", "Fig. 7", "Fig. 8". We should inherit the tradition and accept the inheritance and development of ideas of contemporary under this thinking. It is truly difficult to keep the balance between these two, but it is the goal of our educators and ceramic workers. Thus, these two types of academic education could all show their advantages to promote the development and innovation of ceramic education, so to ceramic education could be developed from all aspects.
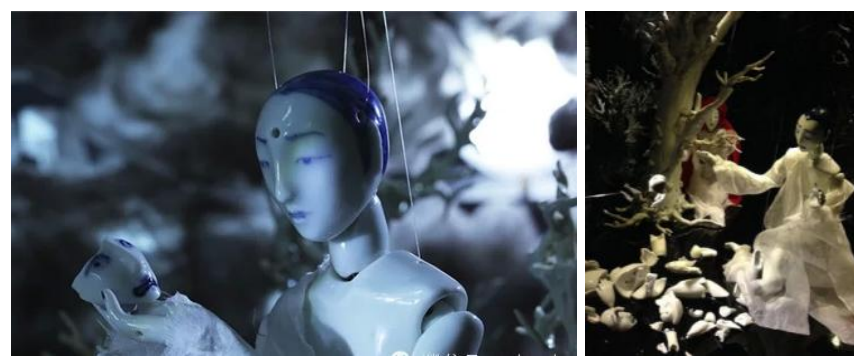

Fig. 4. Student's work of Central Academy of Fine Arts

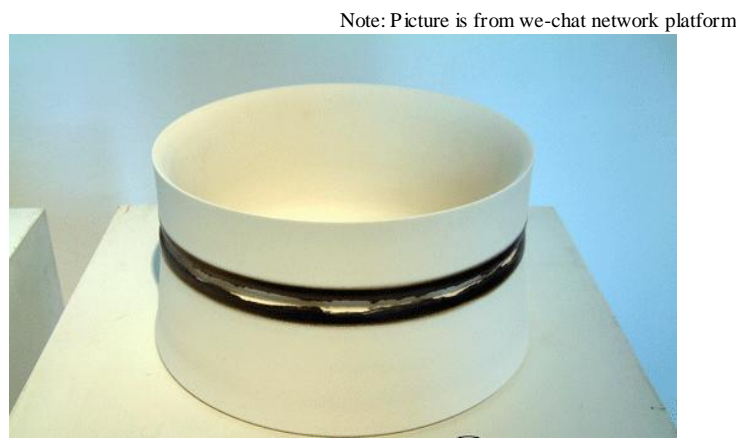

Fig. 5. Early Student's work of China Academy of Art

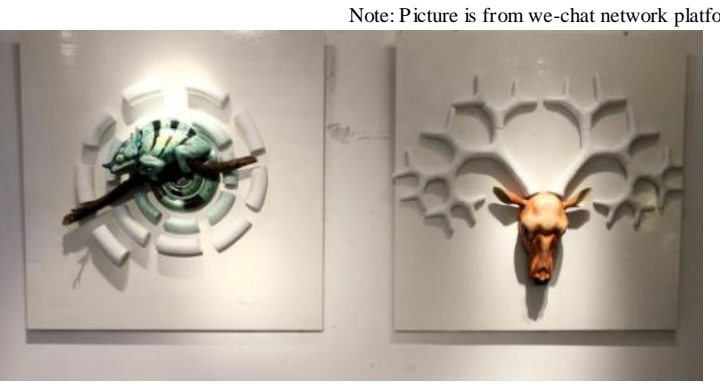

Fig. 6. 2015 Students graduate work of Jingdezhen Ceramic Institute

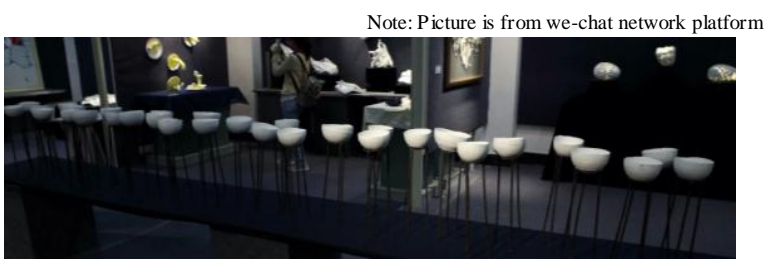

Fig. 7. 2015 Students graduate work of Jingdezhen Ceramic Institute

$$
\text { Note: Picture is from we-chat network platform }
$$




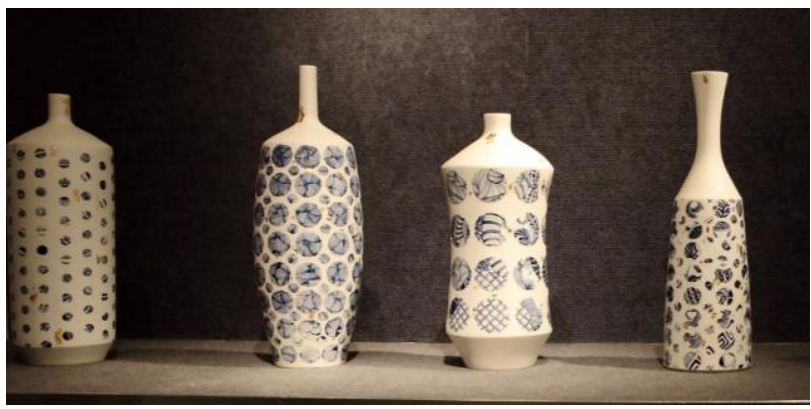

Fig. 8. 2015 Students graduate work of Jingdezhen Ceramic Institute

Note: Picture is from we-chat network platform

\section{B. Mainstream of Chinese Ceramic Education}

\section{1) Two mainstream groups}

Chinese ceramic education, there are two mainstream groups-education of ceramic-production area and academic education, (very similar to the US "School ceramics" and "social ceramic education") each carries distinct cultural functions. The excavation and heritage of traditional culture mainly depend on the major ceramic-production areas; and the universities use contemporary ceramics as a carrier, bear the interpretation of contemporary civilization thought in the individual body. However, the two mainstream education subjects carried their own mission but not conflict with each other. No culture can make isolated and autistic development, all real creations are not negate the traditions, but make evolution in the traditional basis. In the case of multi-culture common development, traditional and modern communion, and symbiosis are inevitable. It is necessary for us to deeply understand our own traditions and based on that, we make the "re-discovery" of the traditions, such as to confirm which angle to pitching-in the current cultural context. This is the only way for Chinese ceramic education to enter the cultural consciousness state, and also the primary mission of current Chinese ceramic educators.

\section{2) Development offoreign ceramic education}

We use Japan and the United States as examples to compare. As we all know, the relationship between Japan and China was deep, so that we feel Japanese and Chinese ceramics are similar. Either porcelain or ceramics, decoration or molding, material selection or firing technology, Japan was directly or indirectly learn from China. They also accepted the influence of Chinese Confucianism, Taoism and Buddhism Culture. They applied pragmatism in culture. He did not try to change materials like Chinese ceramic artists, their attitude toward ceramics is totally respect its language. Different with Chinese traditional ceramic aesthetic, they prefer only nature, only material and only craftwork. They pay attention to sensory experience. In ceramics Aesthetics, the form beauty which supported by technology has become the main features of Japanese ceramics. Secondly, Japan has greatly influenced by Western culture. Because its traditional culture is very deep rooted, traditional ceramics and ceramics influenced by Western are difficult merging and intersection, or we can say they do not blend together well, so they walk their own ways without interrupt each other. This separation state of ceramic creation also reflected in ceramic education. On one hand it emphasizes the natural or simple features, try to reveal the person's own natural artistic ability. Students are encouraged to instinctively express and naturally reveal the language features of mud, fire and glaze, and they take the technology and skill as the starting point and basic of ceramic education, students' study of material connotation and the education of craftwork and technology; on the other hand, emphasize the media's own characteristics as the method and tools of initiate, release and elaborate their potential ability. They advocate for students to discover and explore by themselves, this tendency matches with the Western entire modern philosophy and artistic ideological trends. On the other hand they use "gardener method", which means the teacher should be a gardener to elaborate students' potentials. It emphasis on natural or simple features, try to reveal the person's own natural artistic ability. Focus on the simple beauty of the object has become a traditional Japanese aesthetic sense and characteristics of spirit structure. As shown in "Fig. 9".

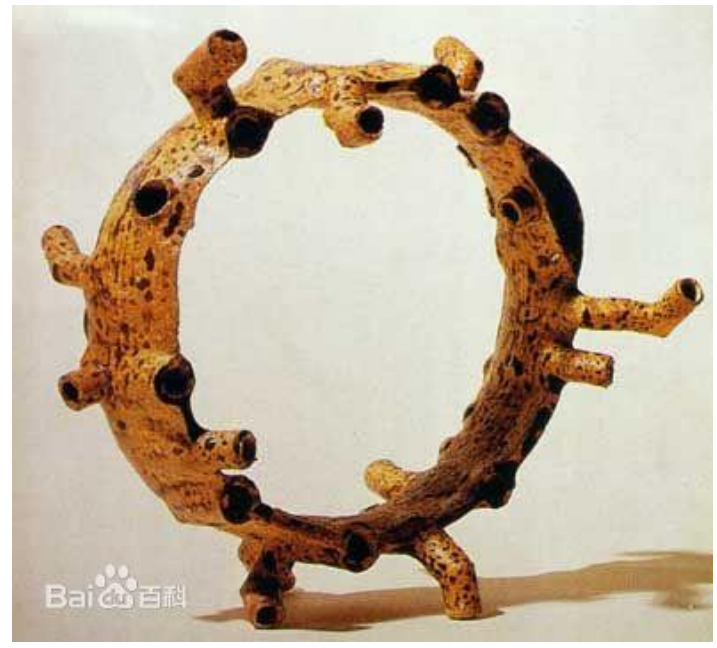

Fig. 9. Kazuo Yagi's ceramic work

Talk about American ceramic education. Dating back to the real ceramic art Higher education is the beginning of the 20th century the Englishman Charles. Fergus · Binkie founded Alfred College of New York State University in 1901. After a hundred years of development, Alfred has become on of the most important institutions of ceramic art Higher education in North America and the world. Meanwhile, there are various kinds of ceramics exhibitions organized by schools, local foundations, associations, galleries and museums in USA, the exhibition are often active and frequent. High-level ceramics performance and ceramic works exhibitions make the ceramic learners, enthusiasts even social populace be edified by what they see, they have a very good education and outreach function. Art Education concept of American University basically based on American educator Bruner's basic structure theory. The famous American educator Elliot Eisner suggested that "art education should based on culture, emphasize that" aesthetics, art history, art creation and Art criticism "were the indispensable curriculum structure content for a complete art education, thus improve the overall perceptual ability of their aesthetic knowledge. In American ceramics Universities, they respect the importance of students' free improvisation in 
education, such as blemishes, cracks and other factors are respect for the material itself to express one aspect of the work. The forms of American ceramic education are mainly two types: "Ceramics school" and "social ceramic education". (which are similar with the two main groups of our domestic ceramic education: ceramic-production area education and academic education) In the end of the 1970s, there were nearly 500 colleges and universities who could provide ceramic art major's bachelor and master degrees in USA, which showed the popularity of ceramic education. In short, the ceramic education of United States based on the concept dominant rather than media dominant, it emphasized the importance of theory, emphasized teachers' culture, training and learning. The overall basic characteristic was the "comprehensiveness". It has ecological characteristics, inclusiveness and humanism, and left enough space for students to free creations. "Fig. 10", "Fig. 11", "Fig. 12", "Fig. 13"

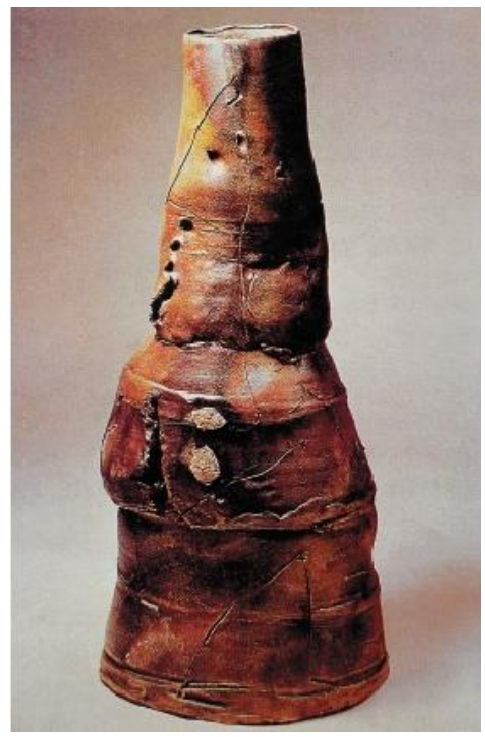

Fig. 10. Peter Voulkos's ceramic work

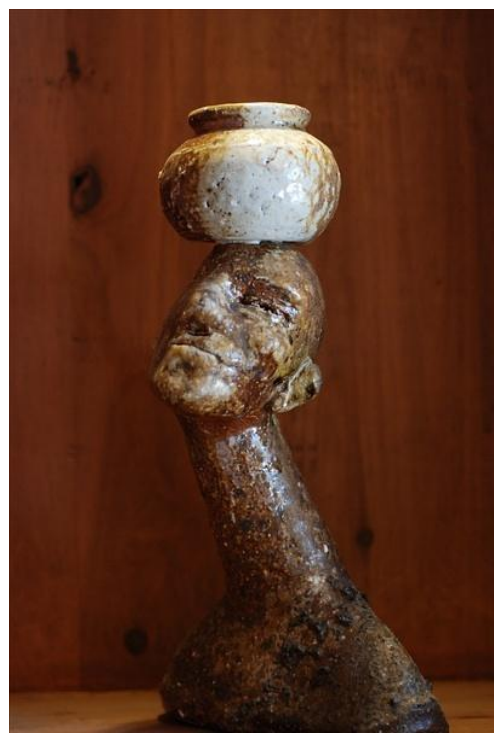

Fig. 11. Artist's ceramic work
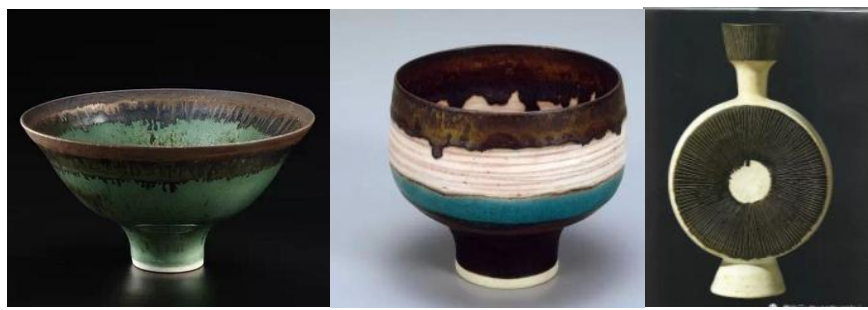

Fig. 12. Lucie Rie's ceramic works

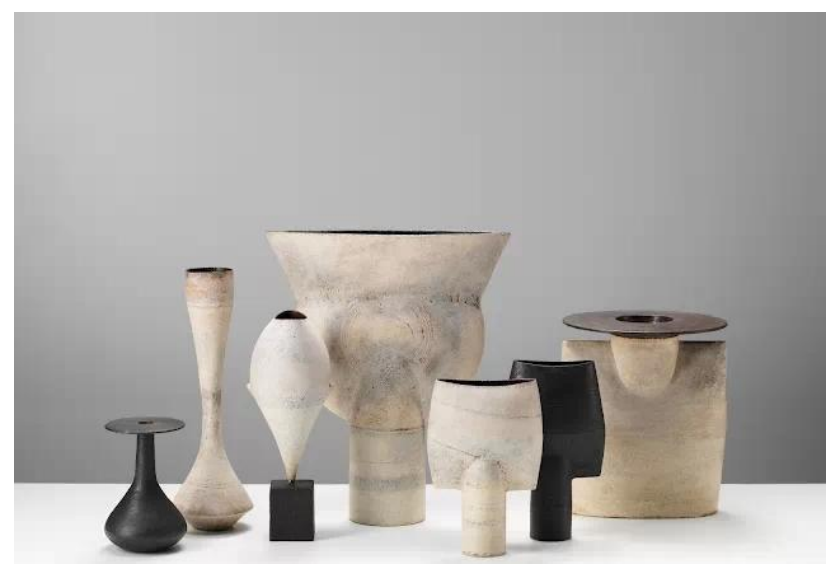

Fig. 13. Hans Coper's ceramic works

Note: All of above pictures are from we-chat network platform

Each country's ceramic education has its own cultural background, in contemporary art backgrounds express each advantages in order to fit the local culture and context educational philosophy, and provides a good learning atmosphere and learning environment to the various levels of ceramic workers, promote our ceramic culture and inherit our ceramic education.

\section{DEVELOPMENT PROSPECTS OF CERAMIC EDUCATION}

Take the Contemporary Ceramics language practice as a concept applied to reality, which is an extension of Modernism in Contemporary Ceramics. Use experience method to achieve aesthetic judgment, which provides the feasibility and purposefulness for contemporary ceramic development, but also exhibit a contemporary feel and the beauty of the third field. Traditional experience set the ceramic works on the social demands (such as political, religious, ethnic), and the new experimentalism set the ceramic quality in an intuitive and stylized mental space, achieved the universality of mental space. Because both of them all permeate the ceramic quality with presentation form, it ignores the similarities and differences with its traditional experience or contemporary doctrine, which gives the ceramics with contemporary features.

Under the artistic ideas of humanity beauty and closely related to people which advocated by contemporary art, this modern craftwork (which is contemporary doctrine) becomes precious. We can see their soul expressions in her carcass, texture and glaze and which happened to coincide with Contemporary Art. This is an expression of one category of 
contemporary ceramics with handmade warmth and happiness. During ceramic education, control this basic technique also plays a very important fundamental role in the early teaching process. In contemporary ceramic education, we could try our best to express the complexity of ceramic material and irreplaceable practice behaviors. That is to say, fully dig the clay material itself and respect the material itself, but also there is an experimental and pioneering spirit in their creations, which left enough spaces for students to display and elaboration. In China, ceramic education after experienced traditional experience, drawing mode, modernism and postmodernism, the contemporary experience spirit effectively predict the trend of contemporary ceramics concept education, respect the tradition but want to get rid of the shackles of it, let it truly express its own spirit, the charm of material itself and contemporary character of cultural quality.

\section{REFERENCES}

[1] Li Li. Discussion on Song Dynasty porcelain modeling with rationalist design thinking [J], China Ceramics, 2012.8.

[2] Zheng Ning. Technology spirit of Song Dynasty porcelain [M], Harbin: Heilongjiang Fine Arts Publishing Company, 2011.

[3] Chen Wenping. Chinese ancient ceramics [M], Shanghai: Shanghai Bookstore Publishing Company, 2003.

[4] Wang Ruiyun. 16 talks about contemporary Western aesthetic [C], Beijing: People's Fine Arts Publishing Company, 2013.

[5] Qin Xilin, Jin Wenwei.Comparison of modern ceramic art education [C], Shanghai: Academia Press, 2008. 